\title{
Application of disease-associated differentially expressed genes - Mining for functional candidate genes for mastitis resistance in cattle
}

\author{
Manfred SCHWERIN ${ }^{\mathrm{a} *}$, Diana CZERnek-SCHÄFer ${ }^{\mathrm{a}}$, \\ Tom Goldammer ${ }^{\mathrm{a}}$, Srinivas R. Kata ${ }^{\mathrm{b}}$, James E. WomacK ${ }^{\mathrm{b}}$, \\ Ravi PAREeK ${ }^{\mathrm{c}}$, Chandra PAReEK ${ }^{\mathrm{c}}$, \\ Krzysztof WALAWSKI ${ }^{\mathrm{c}}$, Ronald M. BRUNNER ${ }^{\mathrm{a}}$ \\ ${ }^{a}$ Research Unit for Molecular Biology, \\ Research Institute for the Biology of Farm Animals, Dummerstorf, Germany \\ ${ }^{b}$ Department of Veterinary Pathobiology, Texas A\&M University, \\ College Station, TX 77843, USA \\ c Department of Animal Genetics, \\ University of Warmia and Mazury, Olsztyn, Poland
}

(Accepted 4 February 2003)

\begin{abstract}
In this study the mRNA differential display method was applied to identify mastitisassociated expressed DNA sequences based on different expression patterns in mammary gland samples of non-infected and infected udder quarters of a cow. In total, 704 different cDNA bands were displayed in both udder samples. Five hundred-and-thirty two bands, $(75.6 \%)$ were differentially displayed. Ninety prominent cDNA bands were isolated, re-amplified, cloned and sequenced resulting in 87 different sequences. Amongst the 19 expressed sequence tags showing a similarity with previously described genes, the majority of these sequences exhibited homology to protein kinase encoding genes (26.3\%), to genes involved in the regulation of gene expression (26.3\%), to growth and differentiation factor encoding genes $(21.0 \%)$ and to immune response or inflammation marker encoding genes $(21.0 \%)$. These sequences were shown to have mastitis-associated expression in the udder samples of animals with and without clinical mastitis by quantitative RT-PCR. They were mapped physically using a bovine-hamster somatic cell hybrid panel and a 5000 rad bovine whole genome radiation hybrid panel. According to their localization in QTL regions based on an established integrated marker/gene-map and their disease-associated expression, four genes (AHCY, PRKDC, HNRPU, OSTF1) were suggested as potentially involved in mastitis defense.
\end{abstract}

\section{mastitis / expressed sequence tag / gene expression / cattle / RH mapping}

\footnotetext{
* Correspondence and reprints

E-mail: schwerin@fbn-dummerstorf.de
} 


\section{INTRODUCTION}

Mastitis is a complex disease that is defined as an inflammation of the mammary gland and which results from the introduction and multiplication of pathogenic microorganisms as Staphylococcus aureus and Streptococcus agalactiae in the mammary gland [15]. In dairy cattle, mastitis is the most costly disease. Costs due to clinical mastitis include veterinary and treatment costs, reduced milk production in the remaining lactation, milk disposal due to antibiotic treatment, early culling, extra labor and decreased milk quality.

During the past 5 years, many experiments have identified a high number of different QTL regions in cattle affecting milk performance, growth, meat quality, exterior, but also functional traits such as mastitis resistance [2-4,6,19,27,34]. QTL positions and highly significant QTL effects repeatedly confirmed in independent studies emphasize the potential value of mapped QTL in selection for mastitis resistance using marker-assisted selection programs. Beyond fine mapping, however, the ultimate target of QTL analysis is the identification of the gene itself. One of the major efforts in this sense is the identification of coding sequences or transcript units [7], especially those that are localized in the QTL region of interest and that are trait-associated expressed. Identification of expressed sequence tags (EST) in tissues in different developmental stages or in phenotypically different individuals contributes not only to positional cloning by the establishment of high density transcript maps but also to a better understanding of the complex physiological process at the cellular level.

The changes in gene expression that are associated with mastitis are not well understood. In one of the first studies it was shown that the infection of multiparous Holstein cows with Streptococcus agalactiae significantly increased levels of mRNA coding for heat shock proteins, several growth factors, and the apoptosis marker testosterone-repressed prostate mucine-2 [30].

The technique of differential display of messenger RNA species originally described by [21], has been applied as a powerful tool for cloning genes that are differentially expressed in various tissues or under altered conditions in the same tissue $[1,10,20,22,24,28]$. In this study, the mRNA differential display method was applied to identify mastitis-associated expressed DNA sequences based on different expression patterns in the mammary gland by a comparative analysis of non-infected and infected udder quarters of a cow. In a combined approach, these sequences were shown to have mastitis-associated expression in a representative number of udder samples of animals with and without clinical mastitis by quantitative RT-PCR using the LightCycler ${ }^{\circledR}$. Their localisation was found to be in the vicinity of mapped QTL underlying the somatic cell score. 


\section{MATERIALS AND METHODS}

\subsection{Differential display RT-PCR (DDRT-PCR)}

DDRT-PCR was performed essentially as described by [10]. Total RNA was extracted from infected and non-infected quarters of a lactating cow using the RNeasy Total RNA Kit (Qiagen, Hilden, Germany). The cDNA was generated by reverse transcription using the Expand ${ }^{\mathrm{TM}}$ Reverse Transkriptase (Boehringer, Mannheim, Germany). For each cDNA sample a total of 6 primer combinations were used. The three downstream primers DP1 (5'-(T) $\left.{ }_{10} \mathrm{G}-3^{\prime}\right)$, DP2 $\left(5^{\prime}-(\mathrm{T}){ }_{10} \mathrm{C}-3^{\prime}\right)$, and DP3 $\left(5^{\prime}-(\mathrm{T})_{10} \mathrm{~A}-3^{\prime}\right)$ were combined with the upstream primers UP1 (5'-GTGAGCTCC-3') and UP2 (5'-AAGCTTCATTCCG-3'). PCR products were resolved on a $4 \%$ native polyacrylamide sequencing gel and the bands were visualized by conventional silver staining.

\subsection{Cloning, cycle sequencing, sequence analysis, and primer design}

The differentially displayed cDNA bands were cloned into Epicurian ${ }^{\circledR}$ Coli XL1-Blue competent cells (Stratagene, Heidelberg, Germany) using the SureClone Ligation Kit (Pharmacia Biotech, Freiburg, Germany).

Five to ten clones of each partial library were randomly selected and sequenced by Taq cycle sequencing with a model 310C sequencer (Perkin Elmer/Applied Biosystems, Weiterstadt, Germany) using the universal M13 primers. Insert sequences were compared with sequences present in the EMBL/Genbank database using FASTA software [25]. As a criterion for homologous genes, a sequence identity of $>70 \%$ for at least 100 base pairs was defined. Primer pairs were designed using the OLIGO software (v.4, Natl. Biosciences Inc., Plymouth, MN, USA).

\subsection{Study of gene expression}

Transcript levels of identified differentially expressed genes were studied in unrelated lactating Holstein Friesian cows with $(\mathrm{n}=10)$ and without $(\mathrm{n}=$ 10) clinical mastitis. Prior to slaughtering, the udders were examined for clinical mastitis. The results were verified histologically. Total RNA was extracted from udder samples using the RNeasy Total RNA Kit (Qiagen, Hilden, Germany) according to the manufacturers instructions. Synthesis of first strand cDNA was performed with MMLV-RT (Promega, Madison, USA) and random hexamer primers using $2 \mu \mathrm{g}$ total RNA.

\subsubsection{Semi-quantitative RT-PCR}

The cDNA was diluted with $80 \mu \mathrm{L} \mathrm{H}_{2} \mathrm{O}$. Five-micro-litres of the dilution were used as the template for PCR analysis. Subsequent PCR was performed 
Table I. List of mammary gland expressed sequence tags (EST) with similarity to known genes: homology, PCR conditions.

(continued on the next page)

\begin{tabular}{|c|c|c|c|c|c|c|c|c|c|c|c|}
\hline \multirow{3}{*}{$\begin{array}{l}\text { Name } \\
\text { of EST }\end{array}$} & \multirow{3}{*}{$\begin{array}{l}\text { GenBank } \\
\text { Acc. No. }\end{array}$} & \multirow{3}{*}{$\begin{array}{c}\text { Length } \\
\text { of EST } \\
{[\mathrm{bp}]}\end{array}$} & \multicolumn{3}{|c|}{ Sequences showing similarities with the bovine EST } & \multicolumn{2}{|c|}{ Similarity } & \multicolumn{3}{|c|}{ PCR-Amplification } & \multirow{3}{*}{$\begin{array}{c}\text { RT-PCR } \\
\text { - Semiquantitave } \\
\text { RT-PCR (A) } \\
\\
\text { - LightCycler- } \\
\text { PCR (B; } \\
\text { fluorescense } \\
\text { aquisition T) }\end{array}$} \\
\hline & & & Name of sequence & Species & Acc.-No. & $\overline{[\%]}$ & overlap [bp] & Primer sequences & $\begin{array}{l}\text { Annealing } \\
\mathrm{T}\end{array}$ & $\begin{array}{l}\text { Length } \\
\text { of } \\
\text { product }\end{array}$ & \\
\hline & & & & & & & & $\begin{array}{l}\text { Forward }\left(5^{\prime}-3^{\prime}\right) \\
\text { Reverse }\left(5^{\prime}-3^{\prime}\right)\end{array}$ & {$\left[{ }^{\circ} \mathrm{C}\right]$} & [bp] & \\
\hline fbn-eg001 & BI347262 & 595 & $\begin{array}{l}\text { Vaccinia related kinase } 2 \\
(V R K 2)\end{array}$ & H. sapiens & AB000450 & 77.7 & 368 & $\begin{array}{l}\text { ATGGAGAGCTTGACTTGTTG } \\
\text { GAGGAGGAGAAGCTGACTGG }\end{array}$ & 55 & 282 & - \\
\hline fbn-eg002 & BI347263 & 572 & $\begin{array}{l}\text { serine/threonine kinase } 9 \\
(\text { STK9) }\end{array}$ & H. sapiens & NM_003159 & 86.4 & 322 & $\begin{array}{l}\text { TAGCATGCATGATTCTCTTC } \\
\text { AGCCTTCATTTGACCTTTTA }\end{array}$ & 55 & 258 & - \\
\hline fbn-eg003 & BI347264 & 471 & $\begin{array}{l}\text { phosphoinositide-specific } \\
\text { phospholipase C epsilon } \\
(P L C E)\end{array}$ & H. sapiens & AF190642 & 87.0 & 409 & $\begin{array}{l}\text { AGCGGGAAGTCTTCTCATAC } \\
\text { ACAGAGCTCTTCAGAACACC }\end{array}$ & 55 & 279 & - \\
\hline fbn-eg009 & BI347270 & 369 & $L Y 75$ & H. sapiens & AF064827 & 83.0 & 226 & $\begin{array}{l}\text { AGACATTGTTTGTGCTTTTT } \\
\text { CCATACCATGTTACCTTTTT }\end{array}$ & 50 & 316 & - \\
\hline fbn-eg010 & BI347271 & 444 & STE20 like kinase $(J I K)$ & H. sapiens & AF181985 & 84.0 & 328 & $\begin{array}{l}\text { TTGGCCATCTCTTCTATTCA } \\
\text { GCAGCAGCTAGTTAAGGTGT }\end{array}$ & 55 & 251 & A \\
\hline fbn-eg018 & BI347317 & 540 & $\begin{array}{l}\text { DNA-dependent protein } \\
\text { kinase catalytic subunit } \\
\text { (DNA-PKcs) }\end{array}$ & H. sapiens & U47077 & 83.9 & 471 & $\begin{array}{l}\text { ACCCAGATGACATCGACAGT } \\
\text { GTGCGCCATCACAAGGAACC }\end{array}$ & 45 & 367 & - \\
\hline fbn-eg022 & BI347321 & 469 & $\begin{array}{l}\text { heterogeneous nuclear } \\
\text { ribonucleoprotein } \mathrm{U} \\
(H N R P U)\end{array}$ & H. sapiens & AF068846 & 92.6 & 445 & $\begin{array}{l}\text { TTGAGATTGCTGCCCGTAAG } \\
\text { GAACTGCATGTTCTGGTAGG }\end{array}$ & 60 & 200 & A \\
\hline fbn-eg023 & BI347322 & 186 & serum amyloid $\mathrm{A}(S A A 3)$ & H. sapiens & X13895 & 76.2 & 185 & $\begin{array}{l}\text { CTGACCCACCAGCTCTAAAG } \\
\text { GAGCTCCGACAATGTTCTAT }\end{array}$ & 55 & 126 & $\mathrm{~B}\left(78^{\circ} \mathrm{C}\right)$ \\
\hline fbn-eg028 & BI347327 & 280 & $\begin{array}{l}\text { cytosolic ovarian } \\
\text { carcinoma antigen } 1 \\
(\text { COVA1) }\end{array}$ & H. sapiens & AF207881 & 94.5 & 271 & $\begin{array}{l}\text { CTGCCTGTGATACTGATTCT } \\
\text { CAAAAGCCCAGCGTAAAAAC }\end{array}$ & 55 & 174 & $\mathrm{~B}\left(78^{\circ} \mathrm{C}\right)$ \\
\hline fbn-eg029 & no entry & 336 & $\begin{array}{l}\text { osteoclast stimulating } \\
\text { factor I }(O S T F 1)\end{array}$ & H. sapiens & AL133548 & 84.4 & 292 & $\begin{array}{l}\text { CAATCAAACCTAAGAACAAG } \\
\text { TCAACATAAAGAACAGCACT }\end{array}$ & 55 & 115 & - \\
\hline fbn-eg030 & no entry & 259 & $\begin{array}{l}\text { nuclear receptor } \\
\text { subfamily } 1(N R 1 D 2)\end{array}$ & H. sapiens & D16815 & 88.8 & 250 & no primer designed & - & - & - \\
\hline
\end{tabular}




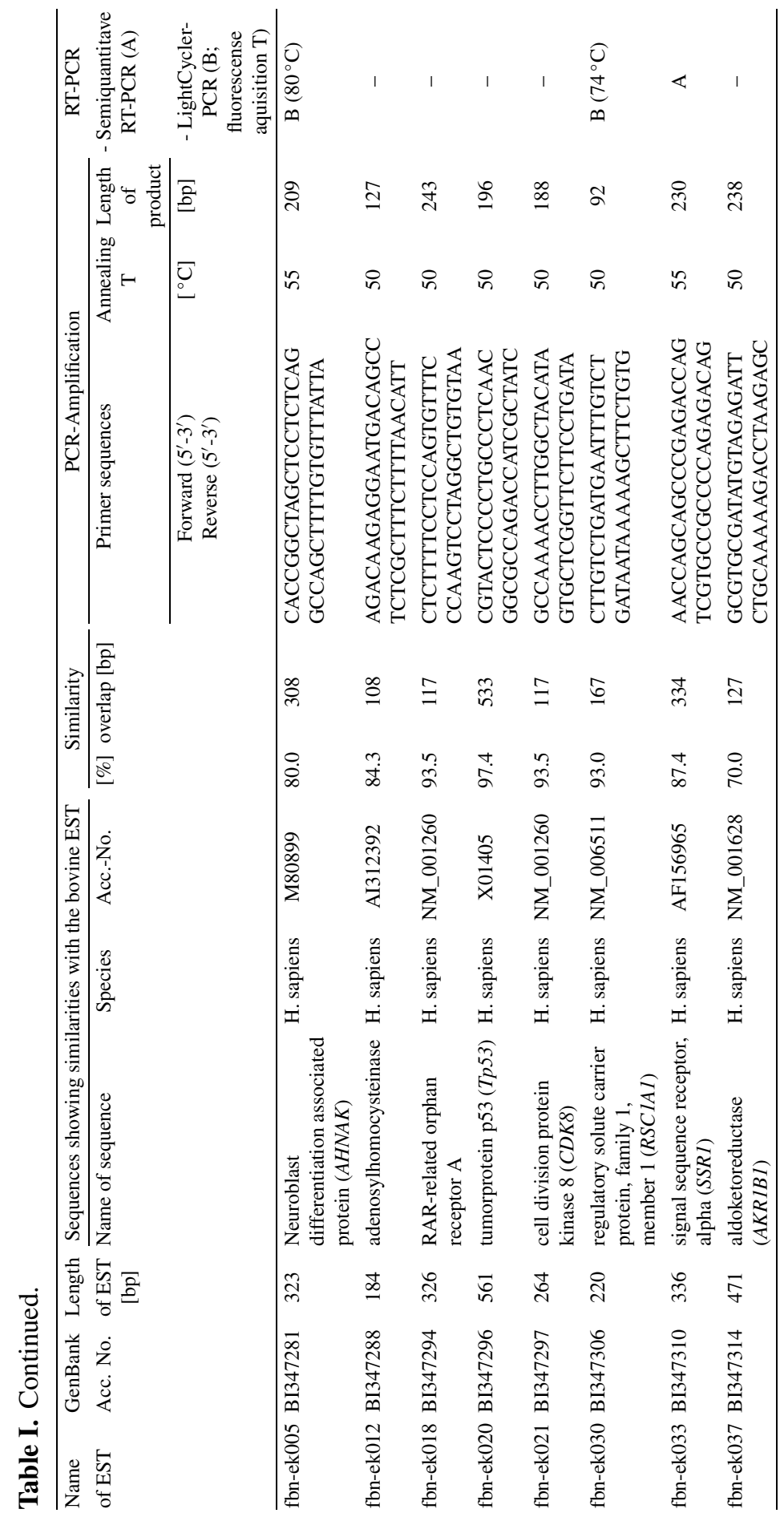


with Taq DNA polymerase (Promega, Mannheim, Germany) in $50 \mu \mathrm{L}$ of incubation buffer, and the primers of the corresponding EST (Tab. I) and of the internal $\beta$-actin standard were used (sense: AACTGGGACGACATGGAGAAGAT, anti-sense: GCCAAGTCCAGACGCAGGAT) for 28 reaction cycles. Electrophoretic PCR patterns were measured densitometrically with the CAM imaging system (Cybertech, Berlin, Germany) and are represented as relative densitometric units (RDU). PCR of the respective samples with $\beta$-actin served as the reference to correct for different loadings of RNA.

\subsubsection{Quantitative RT-PCR}

Quantitative analysis of PCR products was carried out in the LightCycler ${ }^{\circledR}$ (Roche, Mannheim, Germany) according to optimized PCR protocols essentially as described by [29] using the specific primers of the corresponding EST (Tab. I) and LightCycler DNA Master SYBR Green I ${ }^{\circledR}$ (Roche, Mannheim, Germany). Based on the analysis of melting curves of the PCR products, a high temperature fluorescence acquisition point was estimated and included in the amplification cycle program (Tab. I). For all assays, an external standard curve was used based on a single stranded DNA molecule calculation. External DNA standard dilutions of each recombinant plasmid from single stranded DNA ( $10^{\mathrm{x}}$ copies, $\mathrm{x}=1$ to 6 ) were generated from the cloned RT-PCR products into pUC18 vector (Pharmacia, Freiburg, Germany) linearized by a unique restriction digest.

\subsection{Regional assignment by somatic cell genetics}

The generated primer sets were used to identify the loci of the EST in the bovine syntenic groups essentially as described by [33] as well as in the recently published first generation radiation hybrid framework map of the cattle genome [5]. The PCR primer composition and PCR conditions are given in Table I. The EST were assigned to the genome by a two-point linkage which was computed using the RHMAPPER software [32]. The retention frequency was set to the genome average value of 0.22 calculated for the published framework map. For each EST the RH-PCR amplification was performed twice in complete independent experiments, and only concordant data were used.

\subsection{Statistical analysis}

All data were expressed as means \pm standard deviation (SD), and significance was accepted at $P<0.05$. For all analyses, the SAS ${ }^{\circledR} /$ STAT package [26] was used. The means of the quantitative RT-PCR values for all EST of the two groups were compared using a t-test. 


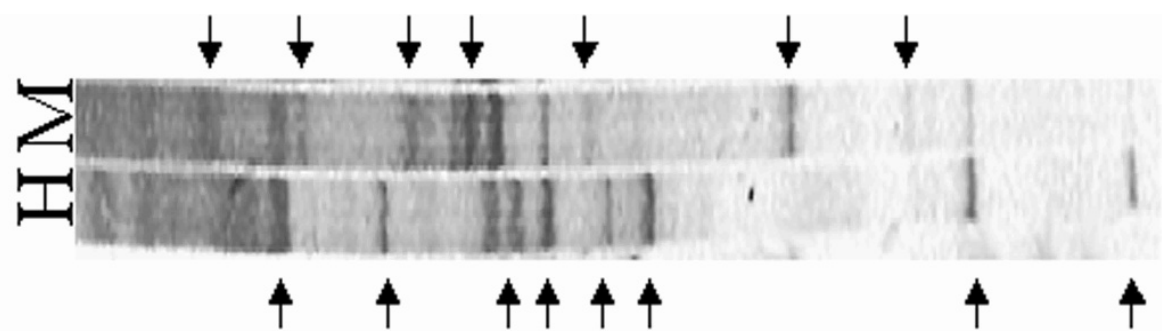

Figure 1. An example of an mRNA differential display of isolates of mastitisinfected (M) and non-mastitis infected $(\mathrm{H})$ udder tissue from quarters of the same cow. Reverse transcription (RT) was done using downstream primer 2 (DP2: $5^{\prime}-(\mathrm{T}){ }_{10} \mathrm{C}-3^{\prime}$ ) and subsequent RT-PCR was done using DP 2 and upstream primers 1 (UP1: $5^{\prime}$-GTGAGCTCC-3'). Products were displayed on a $4 \%$ native DNA sequencing gel, and were visualized by conventional silver staining. The arrows indicate differentially displayed cDNA bands.

\section{RESULTS}

\subsection{Identification of expressed mastitis-associated sequences displayed in DDRT-PCR}

In total 704 different cDNA bands were displayed in both udder samples (see Fig. 1). Five-hundred-and-thirty-two bands (75.6\%) were differentially displayed, of which 232 cDNA bands (43.6\%) were more intensively displayed in the non-infected and 300 cDNA bands $(56.4 \%)$ in the infected quarters of the udder. Amongst the differentially displayed cDNA bands, the most distinguished 90 were isolated, re-amplified, cloned and 5 to 10 clones per cDNA band were sequenced. In most cases, each band consisted of several cDNA. Altogether, 78 different mammary gland EST were identified using this approach. The nucleotide sequence data reported in this paper were submitted to GenBank and have been assigned the accession numbers BI347262 - BI347314. A genome database search showed that 25 EST were similar to previously described or hypothetical genes. Additionally, 11 EST showed similarity with EST of the database and 20 EST did not match any database entries. The rest were similar to repetitive, rRNA or cloned genomic sequences. The name and accession number of the sequences showing similarity to known genes, the length of overlapping fragments, the percentage of homology, the names of the homologous genes, and RT-PCR conditions are reported in Table I. The physiological function of the 19 EST was identified on the basis of their sequence similarity with known genes. The majority of these sequences exhibited homology to the protein kinase encoding genes (5), genes involved in the regulation of gene expression (5), growth and differentiation factors encoding genes (4) and immune response or inflammation marker encoding genes (4). 


\subsection{Mastitis significantly modifies expression profiles in the udder}

The protein kinases encoding genes included the serine/threonine kinase 9 (STK9), the STE20-like kinase (JIK), the cell division protein kinase 8 (CDK8), the DNA-dependent protein kinase $(P R K D C)$ and the vaccina related kinase 2 $(V R K 2)$. The genes related to the regulation of gene expression included the S-adenosylhomocysteine hydrolase encoding gene $(A H C Y)$ acting as a competitive inhibitor of s-adenosyl-I-methionine-dependent methyl transferase reactions, the scaffold attachment factor $\mathrm{A}(H N R P U)$ that binds to pre-mRNA and is a component of ribonucleosomes, the signal sequence receptor $\alpha$ (SSRl) that regulates the retention of endoplasmatic proteins, and two genes coding for nuclear receptors (orphan nuclear receptor nr1d1, $N R D 1$; nuclear receptor ror-alpha, RORA) binding DNA as a monomer to hormone response elements. The growth and differentiation factor encoding genes included three genes involved two regulatory factor encoding genes (osteoclast stimulating factor 1, OSTF 1; regulatory solute carrier protein family 1, RSC1A1), a gene involved in cell differentiation (neuroblast differentiation associated protein ahnak, $A H N A K)$ and a gene acting as a trans-activator negatively regulating cell division and cyclin-dependent kinases (cellular tumor antigen p53, TP53). The four genes involved in the immune response and inflammation processes were, respectively, the cystolic ovarian carcinoma antigen 1 (COVAl), the lymphocyte antigen 75 ( $L Y 75)$, the phospholipase C, epsilon (PLCE) and the serum amyloid A-3 (SSA3). To study the effect of mastitis infection on the gene expression pattern in the mammary gland, mRNA abundance of selected differentially displayed sequences characterizing the different pathways $(J I K$, HNRPU, RSC1A1, AHNAK, SSR1, COVA1, SSA3) was analyzed. The mRNA copy number (in $10 \mathrm{ng}$ total RNA by Real-time PCR) varied between the different genes, from several hundreds to more than one million molecules, probably due to the varying physiological roles of the sequences. The mRNA abundance of these genes in the udder was analyzed in three independent repeated experiments.

Figure 2 represents the relative mean, standard deviation, $x_{\min ^{-}}$and $x_{\max }{ }^{-}$ values of mastitis-associated transcript levels of the genes related to the mean of the non-infected animals. In cows exhibiting clinical mastitis, the mean mammary gland transcription levels of COVA1, SAA3, RSCIA1 and SSR 1 were 1.8-4 times higher than in cows with non-infected udders. In contrast, the mean mRNA abundance of AHNAK, JIK and HNRPU was not significantly different between both groups. However, failing statistical significance is probably due to the extreme inter-individual variability observed in the mastitis group. As shown for AHNAK, SAA3 and RSC1A1, mRNA abundance of individual animals with clinical mastitis ranges from values comparable to that of non-infected animals to about 14-fold increased concentrations (Fig. 3). In general, transcript levels of all genes analyzed were characterized by an 


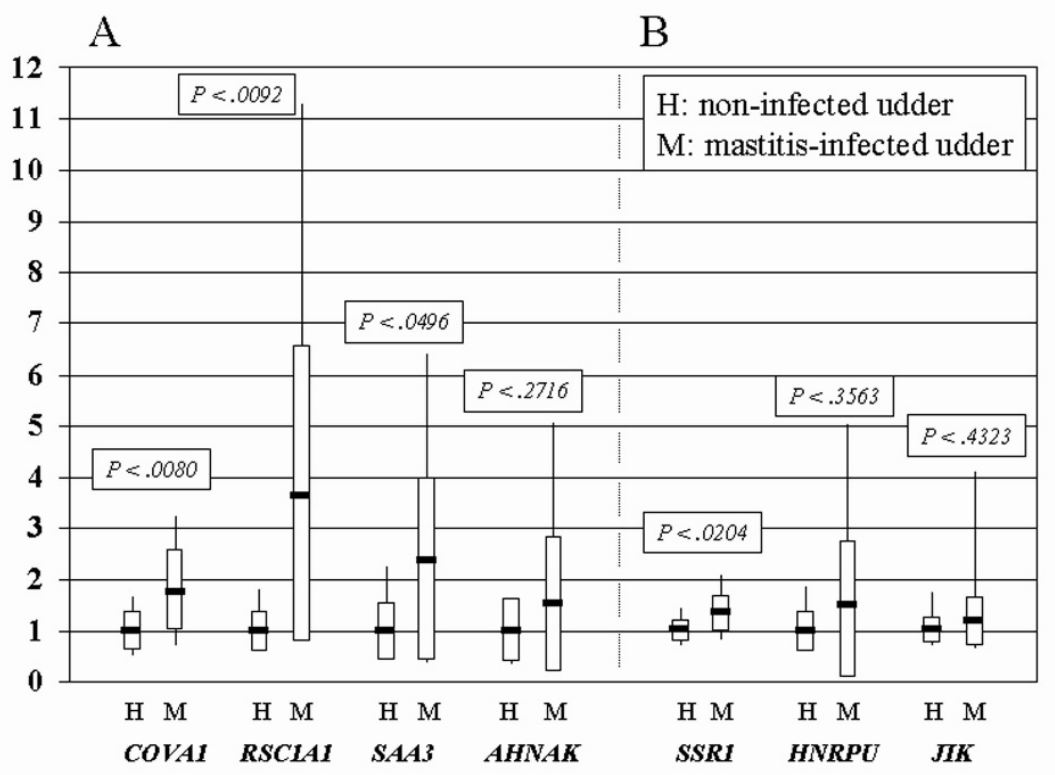

Figure 2. Mean transcript amounts in the mammary gland of ten cows with (M) and without $(\mathrm{H})$ clinical mastitis, relative to the control group (animals without mastitis). The horizontal bold line represents the mean, the rectangle represents twice the SD, and the vertical bars correspond (upper bar) to the maximum and (lower bar) to the minimum. (A) Mean relative mRNA abundance (number of molecules per $10 \mathrm{ng}$ total RNA) of the genes cystolic ovarian carcinoma antigen 1 (COVA1), regulatory solute carrier protein family 1 (RSC1A1), serum amyloid A-3 (SSA3), neuroblast differentiation associated protein ahnak $(A H N A K)$. (B) Mean relative densitometric units of transcripts after semi-quantitative RT-PCR of the genes signal sequence receptor $\alpha(S S R 1)$, scaffold attachment factor A (HNRPU), and STE20-like kinase $(J I K)$ in both groups.

increased inter-individual variability in animals with clinical mastitis as shown by standard deviations significantly higher than that of the control group (Figs. 2 and 3).

\subsection{Mastitis-associated expressed loci map within the vicinity of quantitative trait loci for somatic cell score in cattle}

The four differentially expressed loci OSTF1, AHCY, PRKDC and HNRPU were mapped physically using a bovine-hamster somatic cell hybrid panel (SCP) and a 5000 rad bovine whole genome radiation hybrid panel (WGRH). These loci were assigned to the bovine syntenic groups and positioned in the recently established $\mathrm{RH}$ based ordered comparative map of the cattle genome [5]. The mapping results are summarized in Table II together with 


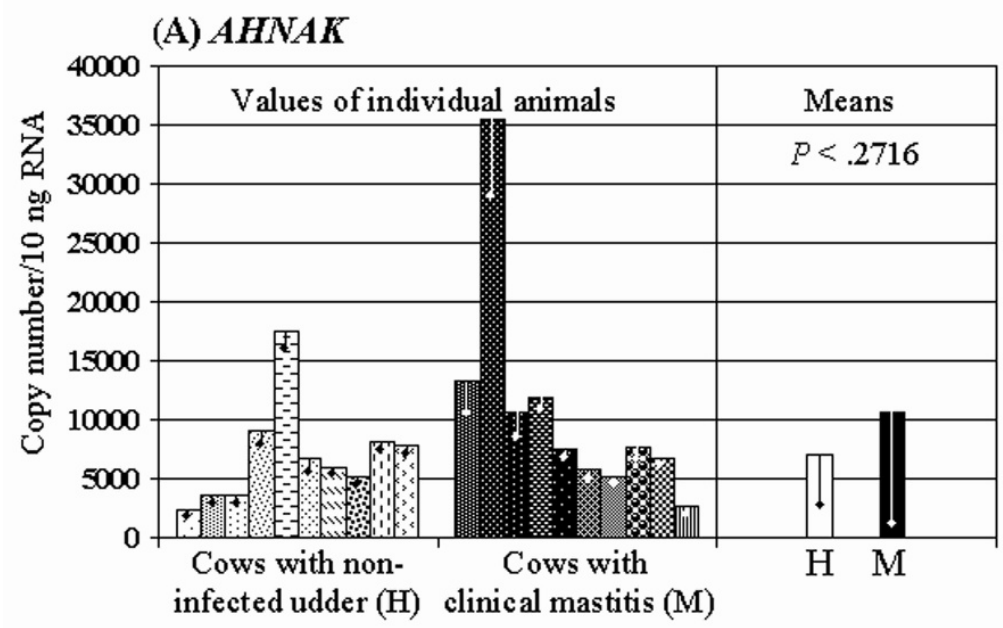

(B) $S A A 3$

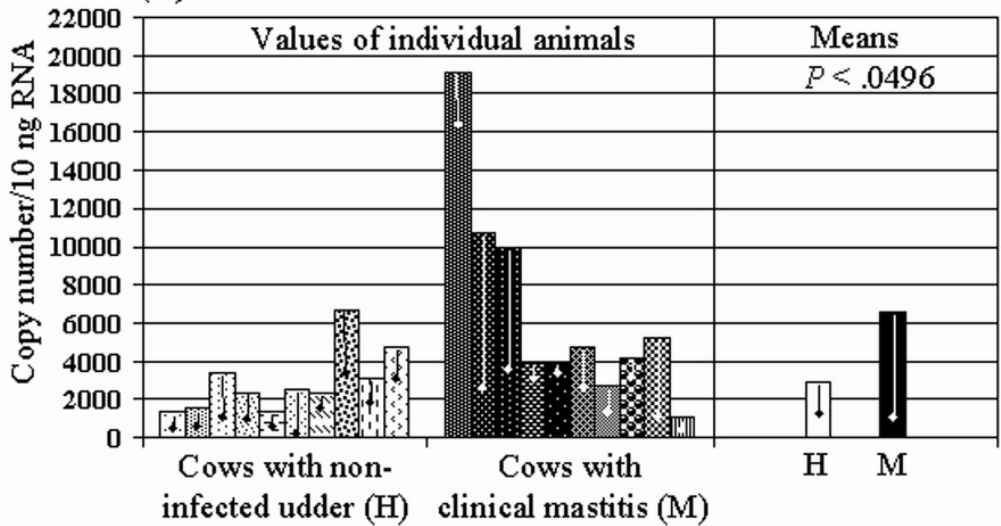

Figure 3. Individual and mean mammary gland mRNA abundance (number of molecules per $10 \mathrm{ng}$ total cellular RNA) of the genes AHNAK (A) and SAA3 (B) in 10 cows with and without clinical mastitis, respectively. Note that individual animals are characterized by specific column patterns. Bars represent SD.

the results from studies on the detection of quantitative trait loci (QTL) for the somatic cell score. In this table, the loci were ordered according to the bovine chromosome numbers. The SCP mapping data show the chromosome location of loci and the calculated concordance values. The WGRH mapping data show the loci location characterized by the nearest microsatellite markers in the RH framework map. In addition, their position in the bovine linkage MARC97 map [18] is given. 
Table II. Results from regional assignment of mastitis-associated expressed loci by somatic cell genetics using a somatic cell panel (SCP) and whole-genome radiation hybrid panel (WGRH) and from studies on the detection of quantitative trait loci (QTL) for somatic cell score in cattle.

\begin{tabular}{|c|c|c|c|c|c|c|}
\hline \multirow[t]{3}{*}{ Locus name } & \multicolumn{3}{|c|}{ Regional assignment } & \multirow{3}{*}{$\begin{array}{l}\text { Position of nearest frame } \\
\text { map micro-satellite marker } \\
\text { within the MARC97 } \\
\text { map }[18][\mathrm{cM}]\end{array}$} & \multicolumn{2}{|c|}{ QTL $_{\text {SCS }}$ positions ${ }^{1}$} \\
\hline & \multirow[t]{2}{*}{$\begin{array}{c}\text { Chromosome } \\
\text { BTA }\end{array}$} & \multirow[t]{2}{*}{$\begin{array}{l}\text { SCP concordance } \\
\text { value }\end{array}$} & $\begin{array}{l}\text { WGRH5000- } \\
\text { Mapping }\end{array}$ & & \multirow[t]{2}{*}[\mathrm{cM}]{} & \multirow[t]{2}{*}{ Reference } \\
\hline & & & $\begin{array}{l}\text { Nearest frame } \\
\text { map [5] } \\
\text { micro-satellite } \\
\text { marker }\end{array}$ & & & \\
\hline OSTF1 & 8 & 100 & BM8129 & 70 & $44-84$ & [19] \\
\hline \multirow[t]{2}{*}{$A H C Y$} & 13 & 97 & BMS995 & 84 & 91 & [33] \\
\hline & & & & & 104 & {$[6]$} \\
\hline$P R K D C$ & 14 & 87 & RM180 & 35 & $24-53$ & [33] \\
\hline$H N R P U$ & 16 & 100 & BMS1348 & 12 & 30 & {$[6]$} \\
\hline
\end{tabular}

${ }^{1}$ Position on the marker map used in the study in which the QTL was detected. 


\section{DISCUSSION}

This study compared mammary gland mRNA patterns of cows with and without clinical mastitis. DDRT-PCR was performed in infected and noninfected quarters of a lactating cow to identify mastitis-associated amplified sequences based on an identical genetic background. Between-cow variation was not considered using this qualitative approach. Differential expression, however, must be confirmed by classical Northern blot analysis, ribonuclease protection assay or quantitative PCR.

Based on 532 differentially displayed cDNA bands, we developed 78 molecular probes. Nineteen EST showing similarity to known genes were applied in transcription studies indicating that clinical mastitis significantly modifies gene expression in the mammary gland. Considering the physiological functions of these genes, significant changes in expression profile indicate a complex activation of gene expression associated with cell proliferation. Both up-regulated expressions of genes involved in cellular signal transduction (protein kinases: STK9, JIK, CDK8, PRKDC, VRK2, TP53; nuclear receptor encoding genes: NRD1, RORA; the cellular trans-activator TP53), and in the regulation of gene expression ( $A H C Y, S S R I, H N R P U)$ and of genes involved in cell growth and differentiation (OSTF1, RSC1A1, AHNAK) characterize highly proliferating cells. Increased proliferation of cells is widely described as a pathophysiological effect of inflammation processes. However, in the present experimental approach of DDRT-PCR, the expression of genes related to increased cell proliferation dominated the mastitis-associated changes of the expression pattern in the mammary gland. Only four of the 19 genes, showing similarity to known genes, are involved in the immune response and inflammation processes. Two of these genes code for antigene (COVAl, LY75) whereas the two other genes code for the acute phase proteins phospholipase $\mathrm{C}$, epsilon and serum amyloid A protein, which are early and sensitive inflammation markers $[14,23,31]$. On the contrary, no putative gene involved in mastitis defense could be detected using the DDRT-PCR approach.

However, the results of previous studies of mastitis-associated gene expression are in correspondence with the present findings. Inflammation of cows with Streptococcus agalactiae significantly increased the levels of mRNA coding for several growth factors [30]. Genes involved in cellular proliferation also represent putative candidate genes that might potentially affect both the resistance and etiology of disease. In humans, variants of genes coding for protein kinase that cause genetic disorders and diseases have been described. Defects in the myotonin protein kinase are the causes of myotonic dystrophy [11,12], whereas defects in the pyruvate kinase genes are the most common cause of chronic hereditary nonspherocytic haemolytic anaemia [17]. Genetic variants 
of DNA-dependent protein kinase that is involved in DNA double-stranded break repair and modulation of transcription are associated with severe combined immunodeficiency, type I [13]. Additionally, defects in TP53 cause different malignomes as germ line cancers and Barrett adenocarcinomas $[9,16]$, and deficiency in $A H C Y$ is one cause of hypermethioninemia [8].

Based on the results of SHC/WGRH mapping and QTL mapping approaches $[6,19,34]$, an established integrated marker/gene map allowed the identification of four genes potentially involved in mastitis resistance: OSTF1 (BTA8), AHCY (BTA13), PRKDC (BTA14) and HNRPU (BTA16), showing that the combination of positional and functional candidate gene approaches represents a helpful prerequisite for cloning of candidate genes with underlying QTL effects. Traitassociation of the corresponding gene variants is under investigation.

\section{REFERENCES}

[1] Aiello L.P., Robinson G.S., Lin Y.-W., Nishio Y., King G.L., Identification of multiple genes in bovine retinal pericytes altered by exposure to elevated levels of glucose by using mRNA differential display, Proc. Natl. Acad. Sci. USA 91 (1994) 6231-6235.

[2] Ashwell M.S., Rexroad C.E. Jr., Miller R.H., van Raden P.M., Mapping economic trait loci for somatic cell score in Holstein cattle using microsatellite markers and selective genotyping, Anim. Genet. 27 (1996) 235-242.

[3] Ashwell M.S., Rexroad C.E. Jr., Miller R.H., van Raden P.M., Da Y., Detection of loci affecting milk production and health traits in an elite US Holstein population using microsatellite markers, Anim. Genet. 28 (1997) 216-222.

[4] Ashwell M.S., Da Y., van Raden P.M., Rexroad C.E. Jr., Miller R.H., Detection of putative loci affecting conformation type traits in an elite population of United States Holsteins using microsatellite markers, J. Dairy Sci. 81 (1998) 1120-1125.

[5] Band M.R., Larson J.H., Rebeiez M., Green C.A., Heyen D.W., Donovan J., Windish R., Steining C., Mahyuddin P., Womack J.E., Lewin H.A., An ordered comparative map of the cattle and human genomes, Genome Res. 10 (2000) $1359-1368$.

[6] Boichard D., Bishop M.D., Detection of QTLs influencing milk production and mastitis resistance with a granddaughter design in Hostein cattle, in: Proceedings of the 48th Annual Meeting of the European Association of Animal Production, 25-28 August 1997, Vienna, Austria, paper G1.2, p. 1.

[7] Collins F.S., Positional cloning moves from perditional to traditional, Nat. Genet. 9 (1995) 347-350.

[8] Deloukas P., Matthews L.H., Ashurst J., Burton J., Gilbert J.G.R., Jones M., Stavrides G., Almeida J.P., Babbage A.K., Bagguley C.L., Bailey J., Barlow K.F., Bates K.N., Beard L.M., Beare D.M., Beasley O.P., Bird C.P., Blakey S.E., Bridgeman A.M., Brown A.J., Buck D., Burrill W., Butler A.P., Carder C., Carter N.P., Chapman J.C., Clamp M., Clark G., Clark L.N., Clark S.Y., Clee C.M., 
Clegg S., Cobley V.E., Collier R.E., Connor R., Corby N.R., Coulson A., Coville G.J., Deadman R., Dhami P., Dunn M., Ellington A.G., Frankland J.A., Fraser A., French L., Garner P., Grafham D.V., Griffiths C., Griffiths M.N.D., Gwilliam R., Hall R.E., Hammond S., Harley J.L., Heath P.D., Ho S., Holden J.L., Howden P.J., Huckle E., Hunt A.R., Hunt S.E., Jekosch K., Johnson C.M., Johnson D., Kay M.P., Kimberley A.M., King A., Knights A., Laird G.K., Lawlor S., Lehvaslaiho M.H., Leversha M., Lloyd C., Lloyd D.M., Lovell J.D., Marsh V.L., Martin S.L., McConnachie L.J., McLay K., McMurray A.A., Milne S., Mistry D., Moore M.J.F., Mullikin J.C., Nickerson T., Oliver K., Parker A., Patel R., Pearce T.A.V., Peck A.I., Phillimore B.J.C.T., Prathalingam S.R., Plumb R.W., Ramsay H., Rice C.M., Ross M.T., Scott C.E., Sehra H.K., Shownkeen R., Sims S., Skuce C.D., Smith M.L., Soderlund C., Steward C.A., Sulston J.E., Swann M., Sycamore N., Taylor R., Tee L., Thomas D.W., Thorpe A., Tracey A., Tromans A.C., Vaudin M., Wall M., Wallis J.M., Whitehead S.L., Whittaker P., Willey D.L., Williams L., Williams S.A., Wilming L., Wray P.W., Hubbard T., Durbin R.M., Bentley D.R., Beck S., Rogers J., The DNA sequence and comparative analysis of human chromosome 20, Nature 414 (2001) 865-871.

[9] de Vries E.M.G., Ricke D.O., de Vries T.N., Hartmann A., Blaszyk H., Liao D., Soussi T., Kovach J.S., Sommer S.S., Database of mutations in the p53 and APC tumor suppressor genes designed to facilitate molecular epidemiological analyses, Hum. Mutation 7 (1996) 202-213.

[10] Dorroch U., Goldammer T., Brunner R.M., Kata S.R., Kuehn C., Womack J.E., Schwerin M., Isolation and characterization of hepatic and intestinal expressed sequence tags potentially involved in trait differentiation between cows of different metabolic type, Mamm. Genome 12 (2001) 528-537.

[11] Fu Y.-H., Pizzuti A., Fenwick R.G. Jr., King J., Rajnarayan S., Dunne P.W., Dubel J., Nasser G.A., Ashizawa T., de Jong P.J., Wieringa B., Korneluk R., Perryman M.B., Epstein H.F., Caskey C.T., An unstable triplet repeat in a gene related to myotonic muscular dystrophy, Science 255 (1992) 1256-1258.

[12] Fu Y.-H., Friedman D.L., Richards S., Pearlman J.A., Gibbs R.A., Pizzuti A., Ashizawa T., Perryman M.B., Scarlato G., Fenwick R.G. Jr., Caskey C.T., Decreased expression of myotonin-protein kinase messenger RNA and protein in adult form of myotonic dystrophy, Science 260 (1993) 235-238.

[13] Gilhar A., Landau M., Assy B., Shalaginov R., Serafimovich S., Kalish R.S., Melanocyte-associated T cell epitopes can function as autoantigens for transfer of alopecia areata to human scalp explants on Prkdc(scid) mice, J. Invest. Dermatol. 117 (2001) 1357-1362.

[14] Groonroos J.O., Laine V.J., Nevalainen T.J., Bactericidal group IIA phospholipase A2 in serum of patents with bacterial infections, J. Infect. Dis. 185 (2002) 1767-1772.

[15] Harmon R.J.J., Physiology of mastitis and factors affecting somatic cell counts, Dairy Sci. 77 (1994) 2103-2112.

[16] Hoolstein M., Sidransky D., Vogelstein B., Harris C.C., p53 mutations in human cancers, Science 253 (1991) 49-53.

[17] Kanno H., Fujii H., Hirono A., Miwa S., cDNA cloning of human R-type pyruvate kinase and identification of a single amino acid substitution (Thr384 $\rightarrow$ Met) 
affecting enzymatic stability in a pyruvate kinase variant (PK Tokyo) associated with hereditary hemolytic anemia, Proc. Natl. Acad. Sci. USA 88 (1991) 8218-8221.

[18] Kappes S.M., Keele J.W., Stone R.T., McGraw R.A., Sonstegard T.S., Smith T.P., Lopez-Corrales N.L., Beattie C.W., A second-generation linkage map of the bovine genome, Genome Res. 7 (1997) 235-249.

[19] Klungland H., Sabry A., Heringstad B., Olsen H.G., Gomez-Raya L., Vage D.I., Olsaker I., Odegard J., Klemetsdal G., Schulman N., Vilkki J., Ruane J., Aasland M., Ronningen K., Lien S., Quantitative trait loci affecting clinical mastitis and somatic cell count in dairy cattle, Mamm. Genome 12 (2001) 837-842.

[20] Li F., Barnathan E.S., Kariko K., Rapid method for screening and cloning cDNAs generated in differential mRNA display: application of Northern blot for affinity capturing of cDNAs, Nucleic Acids Res. 22 (1994) 1764-1765.

[21] Liang P., Pardee A.B., Differential display of eukaryotic messenger RNA by means of the polymerase chain reaction, Science 257 (1992) 967-971.

[22] Liang P., Averboukh L., Pardee A.B., Distribution and cloning of eukaryotic mRNAs by means of differential display: refinements and optimization, Nucleic Acids Res. 21 (1993) 3269-3275.

[23] Mayer J.M., Raraty M., Slavin J., Kemppainen E., Fitzpatrick J., Hietaranta A., Puolakkainen P., Beger H.G., Neoptolmos J.P., Serum amyloid A is a better early predictor of severity than c-reactive protein in acute pancreatitis, Br. J. Surg. 89 (2002) 163-171.

[24] Nishio Y., Aiello L.P., King G.L., Glucose induced genes in bovine aortic smooth muscle cells identified by mRNA differential display, FASEB J. 8 (1994) 103-106.

[25] Pearson W.R., Lipman P.J., Improves tool for biological sequence comparison, Proc. Natl. Acad. Sci. USA 85 (1988) 2444-2448.

[26] SAS ${ }^{\circledR}$ Institute, SAS ${ }^{\circledR} /$ STAT User's Guide, Version 8, Cary, NC: SAS ${ }^{\circledR}$ Institute Inc., 1999.

[27] Schrooten C., Bovenhuis H., Coppieters W., van Arendonk J.A., Whole genome scan to detect quantitative trait loci for conformation and functional traits in dairy cattle, J. Dairy Sci. 83 (2000) 795-806.

[28] Schwerin M., Voigt J., Wegner J., Kuehn Ch., Ender K., Hagemeister H., Gene expression in different tissues of lactating cows of differing metabolic type: 1 . Comparison of mRNA patterns by the differential display method, J. Anim. Physiol. Anim. Nutr. 81 (1999) 113-123.

[29] Schwerin M., Dorroch U., Beyer M., Swalve H., Metges C.C., Junghans P., Dietary protein modifies hepatic gene expression associated with oxidative stress responsiveness in growing pigs. FASEB J. 10.1096/fj.01-0734fje, June 21, 2002.

[30] Sheffield L.G., Mastitis increases growth factor messenger ribonucleic acid in bovine mammary glands, J. Dairy Sci. 80 (1997) 2020-2024.

[31] Shimetani N., Shimetani K., Mori M., Levels of three inflammation markers, C-reactive protein, serum amyloid A protein and procalcitonin, in the serum and cerebrospinal fluid of patients with meningitis, Scand. J. Clin. Lab. Invest. 61 (2001) 567-574. 
[32] Slonim D., Kruglyak L., Stein L., Lander E., Building human genome maps with radiation hybrids, J. Comput. Biol. 4 (1997) 487-504.

[33] Womack J.E., Moll Y.D., Gene map of the cow: conservation of linkage with mouse and man, J. Hered. 77 (1986) 2-7.

[34] Zhang Q., Boichard D., Hoeschele I., Ernst C., Eggen A., Murkve B., PfisterGenskow M., Witte L.A., Grignola F.E., Uimari P., Thaller G., Bishop M.D., Mapping quantitative trait loci for milk production and health of dairy cattle in a large outbred pedigree, Genetics 149 (1998) 1959-1973.

To access this journal online: www.edpsciences.org 